\title{
Efficiency Evaluation and Its Influence Factors of Village Banks from the Perspective of Inclusive Finance
}

\author{
Juan Liu \\ School of Economics and Trade, Guangdong University of Finance and Economics, Luntou Road, \\ Guangzhou, China
}

Keywords: Inclusive finance; Village banks; Operating efficiency; DEA model

\begin{abstract}
Inclusive financial system is aimed to provide financial services to all people, especially to those in poor and low-income people, to meet their effective financial services needs, so as to provide equal credit opportunities to people and eliminate discrimination and injustice in financial service. The village banks provide an effective way for the development of inclusive finance and its financial sustainability and service coverage in rural area contributes to realizing the inclusive finance. This paper evaluates the operating efficiency of 22 village banks with a DEA model, and then analyzes its influence factors. The results show that the sample village banks operate well, while the credit efficiency needs to be improved and the developing scale should be adjusted. There is a significant influence on the efficiency of village banks when considering the development situation of the local economy, loan to deposit ratio of assets. Based on the empirical analysis, some suggestions are put forward.
\end{abstract}

\section{Introduction}

Inclusive financial system is a concept proposed by the United Nations in the International Year of microcredit 2005. It means to provide financial services for the whole society, especially the poor and low-income people, to meet their needs of effective financial services, and provide people with fair opportunities for credit services, so as to eliminate discrimination in financial services. The target group of inclusive finance is the vulnerable group. In the process of financial inclusion for the vulnerable group, we should not only maintain the sustainability of the providers of inclusive financial services, but also achieve the goal of "inclusive". This requires the realization of inclusive finance based on the market mechanism's sustainable development, only by which could the problem of efficiency and fairness in the allocation of financial resources be solved.

In recent years, with the continuous and in-depth promotion of China's financial reform, a series of support policies have been issued to increase financial support for small and micro enterprises, farmers and other vulnerable groups in order to improve financial coverage and availability, as well as promote inclusive financial development. The practice of inclusive finance in China began with the introduction of micro credit technology by rural credit cooperatives in 1999 under the initiative of CBRC. However, the existing financial institutions in stock reform, most small and micro enterprises and farmers are excluded from formal financial services and can only obtain credit services through informal financial channels. In 2007, new rural financial institutions such as rural banks, loan companies and rural mutual funds appeared thanks to the relevant policies of China Banking Regulatory Commission, which also marked the formal implementation of inclusive financial system in China. At the end of 2015, the notice on Promoting Inclusive Financial Development Plan (2016-2020) was issued, which again highlighted the access of various market entities to convenient and safe financial services. In terms of achieving financial inclusion with village banks, the sustainable development of village banks is the prerequisite for achieving a wider range of financial inclusion. The focus of its sustainable development is financial sustainability and service goal sustainability, that is, on the basis of effective operation, village banks can achieve financial sustainability, achieve profitability, expand service coverage, and improve the availability of financial services for vulnerable groups, and this will reflect the efficiency and fairness of inclusive finance. Therefore, it is of great significance and practical demand to reexamine the 
operation efficiency and influencing factors of rural banks based on inclusive financial framework.

The rural micro financial institutions, especially the village banks, have been concerned by the theoretical community. A lot of research have been done in their sustainable development, risk management, performance evaluation, equity structure, management system and other aspects. Dong Chong, Feng Xingyuan and Sun Tongquan (2019) finds out that the situation that the village bank realizes the operation goal of maintaining high profit margin and low credit risk under the policy requirement of supporting agriculture, and can realize the policy goal and its own operation goal at the same time.[1] Yang Xueqi et al. (2019) conclude that as community banks in counties and aiming to support agriculture, the village banks are the main carriers to promote inclusive finance and implement financial poverty alleviation.[2] In the aspect of empirical analysis, based on the investigation of rural credit cooperatives in Northern Jiangsu, Zhu Baojin et al. (2007) use DEA method with unexpected output to evaluate the operation quality of rural credit cooperatives in a certain period.[3] Based on DEA super efficiency model, Wu Shaoxin (2009) studied the operating efficiency of four rural banks in Hubei Province, and found that the main reasons for the differences in operating efficiency of rural banks were capital strength, deposit scale, main business income and other factors.[4] Yu Weiping and Luo Jianchao (2012) applies DEA analysis on the operation performance of four rural banks in Shaanxi Province. They believed that the problems such as small scale, lack of senior talents, low market recognition and narrow business were the factors restricting the development of rural banks, which needs capital increasing and share expansion, appropriately, absorption and cultivation of professional talents, expansion of business scope and improvement of risk control system.[5] Yang Chaojuan (2019) evaluates the efficiency of Chongqing rural banks, and finds that the overall operation efficiency is at a general level, and some rural banks are in a relatively coordinated state.[6] Abdul Qayyum and Munir Ahmad (2012) uses DEA model to compare the credit operation efficiency of Pakistan, Bangladesh, India and other South Asian countries, and evaluated the sustainable development of rural microfinance institutions.[7]

This paper selects 22 rural banks in Guangdong Province, Henan Province, Shandong Province, Sichuan Province, Jiangxi Province, Jiangsu Province, and Beijing, with the relevant practices of Abdul Qayyum and Munir Ahmad (2012) [7] and others for reference, it uses DEA model to evaluate the efficiency of rural bank credit operation, and further explores the influencing factors of the efficiency of rural bank credit operation The corresponding research has certain theoretical significance and practical value for China and Guangdong inclusive financial reform and the development of rural banks.

\section{Evaluation of Credit Operation Efficiency of Rural Banks}

\subsection{Model selection}

As a rural micro financial institution, the village bank is different from the traditional formal finance. However, in spite of the policy objectives and tasks of serving the vulnerable groups, village banks still need to pursue profit-making and sustainable operation, and attach importance to the operational efficiency of institutions, because only when the operation is efficient, village banks can continue to develop for a long time, so that they can help inclusive finance. At present, the financial services provided by rural banks are mainly credit services. Combined with the policy goal of serving rural areas, this paper constructs the evaluation index of credit operation efficiency, evaluates the credit operation efficiency of 22 rural banks by using DEA model, and discusses the factors affecting the credit efficiency of rural banks, which is of great significance to realize the sustainable development of rural banks. Since the goal of inclusive finance is to achieve financial efficiency and equity, especially for the vulnerable groups, the evaluation of credit efficiency of rural banks should pay attention to its profitability and the coverage of serving agriculture, rural areas and farmers. This paper takes the profitability of rural banks and the coverage of serving agriculture, rural areas and farmers as the output indicators of efficiency evaluation.

The operation efficiency of village bank is a comprehensive evaluation of its input and output, which reflects the effective allocation of resources of village bank, and reflects its profitability, 
competitiveness and sustainable development ability comprehensively. Modern efficiency measurement is first put forward by Farrell. He uses technical efficiency and allocation efficiency to measure the efficiency of a company. Among them, technical efficiency indicates the maximum output capacity of a company under a given input, allocation efficiency indicates the ability to use the optimal proportion under a given input price, and the measurement of total economic efficiency is completed by the combination of the two.

There are two ways to evaluate efficiency frontier by DEA model: input-oriented and output-oriented. The former is to measure the proportion of factor input decrease when output is constant, and the latter is to measure the proportion of output increase when input is constant.

Data envelopment analysis (DEA) was first proposed by Charnes, Cooper and Rhodes (1978), which was used to evaluate the non-parametric frontier efficiency of production efficiency. Then it was used to evaluate the efficiency of banks, public institutions, non-profit institutions and other industries.[8] After that, some scholars extended and improved the DEA model. Among them, the standard CRS and VRS are designed by Fare, Grosskopf and Lovell (1994), and further extended to cost and allocation efficiency.[9] Data envelopment analysis (DEA) can be divided into two types: constant return to scale and change of return to scale.

\subsubsection{Constant return to scale model (CRS)}

Suppose there are $N$ enterprises, each enterprise has $K$ kinds of inputs and $m$ kinds of outputs. For the ith enterprise, the inputs and outputs are expressed by $x_{i}$ and $y_{i}$ respectively. The input matrix of $K^{*} n$ is $x$, and the output matrix of $M^{*} n$ is $y$, which represents the data of all $N$ enterprises. DEA aims to construct a nonparametric envelope front on the basis of data points, so that all observed data are above or below the production possibility curve. For each enterprise, the ratio of all outputs to all inputs can be measured. $U$ is the output weight matrix of $M * 1$, and $v$ is the input weight matrix of $K^{*} 1$. The problem of linear programming is to choose the best weight.

$$
\begin{array}{r}
\operatorname{Max}_{u, v}\left(u^{\prime} y_{i} / v^{\prime} x_{i}\right), \\
\text { st } \quad u^{\prime} y_{j} / v^{\prime} x_{i} \leqq 1, j=1,2, \cdots, N, \\
u, v>0
\end{array}
$$

This includes the process of finding $u$ and $v$. In this process, the efficiency measure of the ith enterprise is maximized, and all the efficiency is less than or equal to 1 when there are constraints. With another hypothesis $v$, if $i=1$, there are:

$$
\begin{array}{r}
\operatorname{Max}_{\mu a x}\left(\operatorname{ax}_{j \mathrm{j}}\right),(2) \\
\text { st v: }{ }_{\mathrm{i}}=1, \\
\mu^{\prime},{ }_{\mathrm{j}}-\mathrm{V}, \mathrm{v}_{\mathrm{j}} \leqq 0, \mathrm{j}=1,2, \cdots, \mathrm{N}, \\
\mu, \mathrm{j} \geqq 0
\end{array}
$$

It is not difficult to find that the symbol $u$ becomes $\mu$. Using the binary form of linear programming, we can get:

$$
\begin{array}{r}
\operatorname{Min}_{\theta \text { in }} \theta \mathrm{i}(3) \\
\text { st }-\mathrm{y}_{\mathrm{i}}+\mathrm{Y} \geqq 0, \\
-\mathrm{y}_{\mathrm{i}}-\mathrm{X} \geqq 0, \\
\lambda \geqq 0
\end{array}
$$

In the above formula, $\theta$ is a scalar, $\lambda$ is a constant vector of $N^{*} 1$, and $\theta$ is the efficiency score of the ith enterprise. To meet the efficiency of $\theta \leq 1$, it means that the enterprise is technically effective.

\subsubsection{VRS and scale efficiency}

In the model of constant returns to scale, all the enterprises are assumed to operate on the 
optimal scale, but if there are incomplete competition, changes in financial situation and other phenomena, the enterprises may not operate on the most appropriate scale. Banker, Charnes and Cooper (1984) [8] discussed how to modify the CRS model to VRS model by adding convexity constraint $\left(\mathrm{N} 1^{\prime} \lambda=1\right)$ when the scale reward changes. You can get:

$$
\begin{array}{r}
\operatorname{Min}_{\theta \text { in }} \theta \mathrm{i}(4) \\
\text { st }-\mathrm{y}_{\mathrm{i}}+\mathrm{Y} \geqq 0, \\
-\mathrm{y}_{\mathrm{i}}-\mathrm{X} \geqq 0, \\
\mathrm{~N} 1^{\prime} \lambda=1 \\
\lambda \geqq 0
\end{array}
$$

$\mathrm{N} 1$ 'is the matrix of all $\mathrm{N} * 1$. The method with constraints can form a convex surface which envelops all data more closely than CRS, so the technical efficiency is higher than or equal to CRS.

The technical efficiency obtained by CRS model can be divided into scale efficiency and pure technical efficiency. If the two technical efficiencies are different for a specific enterprise, it means that the enterprise has scale inefficiency.

\subsection{Selection of indicators}

When DEA is used to analyze the operation efficiency of rural micro financial institutions, the selection of input and output indicators will affect the efficiency of each decision-making unit directly. Generally speaking, there are three methods as the basis of choice: production method, intermediary method and asset method. Production law starts from the production process of financial institutions. The input of financial institutions is labor, capital, cost, etc., and the output is deposits and loans.[1] In the intermediary law, financial institutions are regarded as intermediaries providing financial services. They invest in capital, labor, deposits, and produce loans and investments. The asset law still regards financial institutions as intermediaries, but the input is the liability item in the balance sheet and output is the capital item. Rural banks mainly serve farmers and small and micro rural enterprises. The purpose of their service is how to allocate financial resources effectively so that more farmers can enjoy financial services. As a financial intermediary, the nature of service is relatively obvious. At the same time, the commercial goal of pursuing profits should be taken into account. Thus, when determining the input and output targets, the above mission of village banks should be taken into account. At present, Yaron's coverage rate and sustainable management standard are widely used to evaluate the efficiency of rural micro financial institutions in the world, and the coverage target and profit target are evaluated respectively (1994). Referring to the existing practice of relevant research, as shown in Table 1, the intermediary method and asset method are selected as the basis. Considering the operation characteristics and data availability of village banks, this paper selects the number of institutions, business outlets, capital, loanable funds and non-interest operating expenses as the input indicators, and the proportion of agricultural loans and the return on assets as the output indicators. The proportion of loans related to agriculture can not only reflect the loan capacity, but also reflect the strength of rural banks in serving farmers and small and micro enterprises, as well as the coverage of rural banks in serving rural areas. The asset yield reflects the profitability of rural banks.[10-12] 
Table 1 Input and output indicators of credit and loan operating efficiency of rural micro-finance institutions in some researches

\begin{tabular}{|c|c|c|}
\hline References & Input indicators & Output indicators \\
\hline $\begin{array}{c}\text { Abdul Qayyum and Munir } \\
\text { Ahmad (2012) [7] }\end{array}$ & $\begin{array}{c}\text { Number of loan counselors, average cost per } \\
\text { borrower }\end{array}$ & loan \\
\hline Mamiza Haq (2010) [13] & Average cost per depositor & $\begin{array}{c}\text { Normal loan, non-interest } \\
\text { income, bad loans }\end{array}$ \\
\hline $\begin{array}{c}\text { ZHU Baojin, ZHANG Lan, } \\
\text { WANG Juan (2007) [3] }\end{array}$ & $\begin{array}{c}\text { Loanable funds, non-interest operating } \\
\text { income.net value of fixed assets }\end{array}$ \\
\hline LIU Lihong (2010) [12] & $\begin{array}{c}\text { Number of employees. operating expense } \\
\text { ratio }\end{array}$ & $\begin{array}{c}\text { Profit per capita, return on } \\
\text { assets, return on capital }\end{array}$ \\
\hline WU Shaoxin (2009) [4] & Number of employees, capital fund, cost of \\
main service & $\begin{array}{c}\text { Revenue of main service, } \\
\text { deposit, net profit }\end{array}$ \\
\hline YU Weiping, LUO Jianchao \\
(2012) [5] & Operating expenses, interest expense, \\
loanable fund, number of employees & $\begin{array}{c}\text { Loan balance, interest revenue, } \\
\text { net profit }\end{array}$ \\
\hline $\begin{array}{c}\text { LI Yanchun (2012) [11] } \\
\text { Labor, net value of fixed assets, deposit } \\
\text { Loan, profit, interest and } \\
\text { non-interest revenue }\end{array}$ \\
\hline
\end{tabular}

Resources: collected from the above references.

\subsection{Data description}

This paper selects 22 rural banks in Guangdong, Henan, Shandong, Sichuan, Jiangxi, Jiangsu and Beijing and all of the selected village banks are Zhujiang village banks with Guangzhou rural commercial bank as the largest shareholder, 15 of which opened in 2011 and 7 opened in 2012. They are distributed in 7 provinces (municipalities directly under the central government) with different degrees of economic development and have been continuously operated up to now. This paper measures the general operation of each village bank from the deposit loan ratio, equity return, non-performing loan ratio and other indicators.

The deposit loan ratio of the 22 rural banks selected in this paper is higher. Except for Huaibin, Huangchuan, Laiwu, Xinyang and Mentougou, the average deposit loan ratio of the other 17 banks in three years is more than $75 \%$, which means that most of the Pearl River rural banks are weak in risk resistance from the perspective of deposit loan ratio.

The stable trend of the return on equity implies the same stable profit rate. From the data of 22 rural banks, the return on equity of each bank is not high in the early stage of establishment. Only 7 rural banks have a positive return on equity in the year of establishment, while the rest banks have a negative return on equity in the year of establishment. However, in the following two years, the return on equity of each bank has increased, indicating that there is profit potential.[11]

From the data of non-performing loan rate, the non-performing loan rate of more than $70 \%$ of Zhujiang village banks is 0, only Qidong Zhujiang bank has a high non-performing loan rate in three years, which are $2.99 \%, 10.38 \%$ and $5.32 \%$ respectively. It can be seen that the loan quality of Zhujiang village bank is good and the security of credit assets is high.

The capital adequacy ratio reflects the extent to which commercial banks can bear the losses with their own capital after the assets of depositors and creditors suffer losses.[12] Under normal conditions, the capital adequacy ratio of systemically important banks and non systemically important banks shall not be less than $11.5 \%$ and $10.5 \%$ respectively. The capital adequacy ratio of 22 Zhujiang village banks is far higher than this standard.

From the three-year deposit loan ratio, non-performing loan ratio, return on equity and capital adequacy ratio of 22 Zhujiang village banks, it can be seen that in general, the business condition, asset quality, profitability and repayment ability of village banks are good. Moreover, each bank carries out the reform through various ways, such as organization system, operation mechanism, product design, etc., in order to maintain the financial sustainability and meet the financial needs of rural areas at the same time.

\subsection{Empirical results}

The operation data of 22 rural banks in 2015 are selected as sample data, oriented by input and 
output respectively, and DEA is used to evaluate the operation efficiency of rural banks. The results are shown in Table 2.

Table 2 Operation efficiency of 22 rural banks

\begin{tabular}{|c|c|c|c|c|c|c|c|c|}
\hline \multirow{2}{*}{$\begin{array}{c}\text { Name of } \\
\text { village } \\
\text { banks }\end{array}$} & \multicolumn{4}{|c|}{ Input-oriented } & \multicolumn{4}{|c|}{ Output-oriented } \\
\hline & $\begin{array}{c}\text { Technology } \\
\text { Efficiency } \\
\text { crste }\end{array}$ & $\begin{array}{c}\text { Pure } \\
\text { Technology } \\
\text { Efficiency } \\
\text { vrste }\end{array}$ & $\begin{array}{c}\text { Scale } \\
\text { efficiency }\end{array}$ & $\begin{array}{l}\text { Returns to } \\
\text { Scale }\end{array}$ & $\begin{array}{c}\text { Technology } \\
\text { Efficiency } \\
\text { crste }\end{array}$ & $\begin{array}{c}\text { Pure } \\
\text { Technology } \\
\text { Efficiency } \\
\text { vrstevrste }\end{array}$ & $\begin{array}{c}\text { Scale } \\
\text { efficiency }\end{array}$ & $\begin{array}{l}\text { Returns to } \\
\text { Scale }\end{array}$ \\
\hline Huaibin & 1.000 & 1.000 & 1.000 & constant & 1.000 & 1.000 & 1.000 & constant \\
\hline Huangchuan & 1.000 & 1.000 & 1.000 & constant & 1.000 & 1.000 & 1.000 & constant \\
\hline Sanshui & 0.973 & 1.000 & 0.973 & diminishing & 0.973 & 0.973 & 1.000 & constant \\
\hline Huixian & 0.960 & 1.000 & 0.960 & increasing & 0.960 & 1.000 & 0.960 & diminishing \\
\hline Heshan & 0.732 & 1.000 & 0.732 & diminishing & 0.732 & 0.732 & 1.000 & constant \\
\hline Laiwu & 0.933 & 1.000 & 0.933 & increasing & 0.933 & 1.000 & 0.933 & diminishing \\
\hline Dongfeng & 0.900 & 1.000 & 0.900 & diminishing & 0.900 & 0.900 & 1.000 & constant \\
\hline Pengshn & 1.000 & 1.000 & 1.000 & constant & 1.000 & 1.000 & 1.000 & constant \\
\hline Guanghan & 0.802 & 0.808 & 0.992 & increasing & 0.802 & 0.886 & 0.905 & diminishing \\
\hline Xinjin & 0.677 & 0.734 & 0.923 & diminishing & 0.677 & 0.840 & 0.806 & diminishing \\
\hline Qidong & 1.000 & 1.000 & 1.000 & constant & 1.000 & 1.000 & 1.000 & constant \\
\hline Xuyi & 1.000 & 1.000 & 1.000 & constant & 1.000 & 1.000 & 1.000 & constant \\
\hline Changning & 1.000 & 1.000 & 1.000 & constant & 1.000 & 1.000 & 1.000 & constant \\
\hline Dalian & 0.966 & 1.000 & 0.966 & diminishing & 0.966 & 1.000 & 0.966 & increasing \\
\hline Jizhou & 0.719 & 0.767 & 0.937 & diminishing & 0.719 & 0.810 & 0.887 & diminishing \\
\hline Laizhou & 1.000 & 1.000 & 1.000 & constant & 1.000 & 1.000 & 1.000 & constant \\
\hline Haiyang & 1.000 & 1.000 & 1.000 & constant & 1.000 & 1.000 & 1.000 & constant \\
\hline Anyang & 1.000 & 1.000 & 1.000 & constant & 1.000 & 1.000 & 1.000 & constant \\
\hline Xinyang & 0.236 & 0.265 & 0.890 & diminishing & 0.236 & 0.840 & 0.280 & diminishing \\
\hline Fushan & 1.000 & 1.000 & 1.000 & constant & 1.000 & 1.000 & 1.000 & constant \\
\hline Mentougou & 1.000 & 1.000 & 1.000 & constant & 1.000 & 1.000 & 1.000 & constant \\
\hline Chengyang & 1.000 & 1.000 & 1.000 & constant & 1.000 & 1.000 & 1.000 & constant \\
\hline $\begin{array}{l}\text { Average } \\
\text { value }\end{array}$ & 0.904 & 0.935 & 0.964 & & 0.904 & 0.954 & 0.943 & \\
\hline
\end{tabular}

First, 22 Pearl River village banks operates efficiently. According to the input-oriented analysis, the average value of technical efficiency, pure technical efficiency and scale efficiency of 22 Zhujiang village banks are $0.904,0.935$ and 0.964 respectively. As to the output oriented analysis, the average values of technical efficiency, pure technical efficiency and scale efficiency of 22 Zhujiang village banks are 0.904, 0.954 and 0.943, respectively. Among them, 12 Pearl River village banks in Huaibin, Huangchuan, Pengshan, Qidong, Xuyi, Changning, Laizhou, Haiyang, Anyang, Fushan, Mentougou and Chengyang, all showed technical efficiency, pure technical efficiency and scale efficiency, accounting for $54.5 \%$ of the total sample banks. The technical efficiency of Pearl River village bank in Xinyang is the lowest, which shows that it has a lower pure technical efficiency value when it is input-oriented, and a lower scale efficiency when it is output-oriented.

Secondly, the credit efficiency and scale of sample village banks need to be improved. The average value of pure technical efficiency of sample banks is the lowest in input-oriented analysis, and 4 banks fail to reach the average value. The average value of scale efficiency of sample banks is the lowest in output-oriented analysis, and 6 banks fail to reach the average value. This shows that, if we want to improve efficiency without reducing output, we should improve pure technical efficiency and credit technology; if we want to improve efficiency without increasing input, we need to adjust appropriately according to the change of scale reward. For a bank with increasing scale reward, its business scale should be expanded approximately, and for the six banks with decreasing scale reward, the operation scale should be reduced so as to improve their operation scale.

Third, most of the Pearl River village banks have good profitability and they serve a lot of farmers and small and medium-sized enterprises. Taking the return on assets as the output index to measure the profitability, and the proportion of loans from farmers and small and medium-sized enterprises as the output index to measure the realization of the service objectives of the village and 
town banks, we get a better result. As one of the main forms of rural micro financial institutions, the main goal of rural banks is to serve the "three rural areas", and allocate financial resources for the development of rural economy. Further analysis of the proportion of farmers' loans in loans shows that rural banks tends to serve small and medium-sized enterprises, because of their fast capital circulation and good production situation and quick repayment in good production situation, which is one of the reasons for the good profitability of rural banks.

\section{Analysis on the influencing factors of credit operation efficiency of rural banks}

Further analysis of the factors affecting the operation efficiency of rural banks may improve the operation efficiency of rural bank credit, so that it can better serve the "three rural".

\subsection{Empirical model and research hypothesis}

In addition to some input and output factors mentioned above, the development of rural banks is also affected by external factors such as government policies, regional economic development and agricultural development. Considering that the operation efficiency of rural banks is between 0 and 1, Probit model is selected to analyze the impact of various factors on the operation efficiency. The original model of binary Probit discrete model is:

$$
\mathrm{Yi}=\mathrm{a}+\beta \mathrm{Xi}+\mu \mathrm{i}, \mathrm{i}=1,2, \ldots, \mathrm{N}
$$

We still select the data of Pearl River Village bank's operation in 2015 for analysis, and determine the corresponding indicators of the external economic environment, internal operation and management conditions and other factors that may affect the development of village banks, which includes the annual per capita income of farmers, the proportion of the total agricultural output value to the GDP, the proportion of the total assets, the number of customer managers to the total number of people, and the ratio of deposits and loans. The research hypothesis is as following:

1) The relationship between the ratio of agricultural output value to GDP and the operation efficiency of rural banks is uncertain. The proportion of total agricultural output value to GDP can indicate the level of local agricultural development. On one hand, it shows that the local economic development is dominated by agriculture, and the rural banks serving farmers and micro enterprises have more loan opportunities, and can also obtain more interest income accordingly. The proportion of total agricultural output value to GDP may be positively related to the operation efficiency of rural banks; On the other hand, in the areas where agriculture is the main industry, the single amount of rural banking business is small and the operating cost is high. Then, the proportion of agricultural gross output value in GDP may be negatively related to efficiency.

2) The proportion of customer managers in the total number is positively related to the efficiency of rural banks. A large number of customer managers means that more human resources take part in the service for farmers and micro enterprises, which can improve the service efficiency to some extent.

3) The annual per capita income of farmers is positively related to the efficiency of rural banks. The proportion of the annual per capita income of local farmers and the total agricultural output value in the GDP can reflect the local rural economic development level. The rural banks in the areas with high economic development level may take more deposit and this will increase the loanable funds. Then the profit and operation efficiency may be improved.

4) The total assets and loan to deposit ratio are positively related to the efficiency of rural banks. In theory, the larger the scale of financial institutions, the more economies of scale can be obtained, so that the operation efficiency may be improved. The high deposit loan ratio indicates that financial institutions have strong capital allocation ability and high operation efficiency.

\subsection{Regression results}

Regression analysis results show that the proportion of the number of customer managers in the total number of people fails to pass the significance test, and the regression results of other independent variables are as follows: 
First, the p value of the index of the proportion of the total agricultural output value to the GDP is 0.045 , indicating that the variable is significant at the level of $5 \%$. The large proportion indicates that the local economic development is dominated by agriculture, and the loan demand of agricultural enterprises and farmers is large, which can bring more interest income to the bank.

Second, the annual per capita income of farmers is positively related to the efficiency of rural banks at the level of $10 \%$. This result is consistent with the hypothesis. The higher annual per capita income of farmers means that farmers have more surplus funds deposited in the bank and this will increase the loanable funds of the bank.

Third, the total assets and the ratio of loan to deposit is negatively related to the operation efficiency of rural banks at the level of $5 \%$ and $10 \%$ respectively. This result is contrary to financial theory and hypothesis. Combined with the analysis of operation efficiency, 6 out of 7 village banks with invalid scale are decreasing in scale, which indicates that some village banks fail to achieve scale efficiency in their development In a situation that the scale growth is too fast and leads to the decrease of operation efficiency, the result has certain significance.

Fouth, there is no significant relationship between the number of customer managers and the operation efficiency. The negative coefficient indicates that there are too many customer managers in rural banks, but they can not provide effective services.

\section{Conclusions and Policy Recommendations}

From the perspective of Inclusive Finance, this paper uses DEA method to evaluate the operation efficiency of 22 rural banks. Taking the ratio of return on assets and the proportion of loans related to agriculture as output indicators, it analyzes the profitability and service coverage of rural banks, observes the degree of inclusive finance, and then analyzes the factors affecting the operation efficiency. The following conclusions and policy implications are drawn:

(1) All the sample banks operate effectively in general. From the input-oriented and output-oriented analysis, 22 rural banks have good overall operation efficiency, and they can effectively control their risks and ensure the sustainable business of rural banks. Also, they can promote their service in the main grain production areas and the areas where the small and micro enterprises clusters, so as to serve the "three rural areas" better.

(2) According to the analysis of input and output indicators, about $20 \%$ of sample banks' pure technical efficiency has not reached the average value, which shows that the improvement of credit technology can improve the credit operation efficiency of rural banks. We should explore credit technology suitable for the development of "agriculture, rural areas and farmers”, establish relevant credit policies, improve credit process, and promote micro credit technology, innovate financial products, so as to improve the financial services and expand the coverage of inclusive financial services.

(3) Output oriented analysis shows that $27.3 \%$ of the sample rural banks fail to achieve scale efficiency. And the asset status, deposit loan ratio are negative related to the operation efficiency of rural banks. This shows that the scale of rural banks may grow too fast, which leads to the decline of operating efficiency. At the same time, the proportion of rural banks serving "agriculture, rural areas and farmers" also needs to be improved. Therefore, rural banks should not expand their scale blindly. This requires the village banks to improve their service, expand the intermediary business actively, improve the capacity of absorbing deposits to expand deposit scale. At the same time, the village banks should increase the service coverage for "the agriculture, rural areas and rural residents", and take into account the profitability and service of inclusive finance.

(4) The proportion of total agricultural output value to GDP, the annual per capita income of farmers are positively related to the operation efficiency of rural banks. There is a large demand for agricultural loans in areas with better agricultural development. The market orientation of rural banks is mainly the county, community and supporting small farmers. The funds are mainly used to issue loans for "agriculture, rural areas and farmers" and small and micro enterprises. Serving small and micro agricultural enterprises is the main embodiment of rural banks to help inclusive finance, and small and micro enterprises are the key service customers of rural banks in the process of 
realizing inclusive finance. Rural banks need to set up flexible financing conditions, provide financing methods consistent with their characteristics, and find the financial needs of small and micro enterprises. For small and micro enterprises in rural areas, bills and contracts can be used as the evidence for evaluating their business conditions. The dynamic incentive mechanism for interest rates can be established, and preferential interest rates should be set according to the number of loans and repayments of small and micro enterprises, so as to reduce the bank risk while maintaining the long-term trading relationship between banks and enterprises. Under the premise of controllable risk, we should control the risk tolerance of small business of agricultural support within a reasonable range, enhance the internal power of small business of agricultural support, and help to realize inclusive Finance.

\section{Acknowledgements}

This work was sponsored by Research project of Humanities and Social Sciences in General Colleges and Universities of Guangdong Province (2013WYM0030).

\section{References}

[1] Dong Chong, Feng Xingyuan, Sun Tongquan. Research on compatibility of operating target and policy target of rural banks. Academics, 2019, 8: 131-140.

[2] Yang Xueqi, Cai Yangping. Analysis of the problems and Countermeasures in the development of Inclusive Finance assisted by rural banks in China. Times Finance, 2019, 25: 94-96.

[3] Zhu Baojin, Zhang Lan, Wang Juan. Operating efficiency and influence factors of Chinese rural credit co-operatives. China Rural Survey, 2007, 1: 11-23.

[4] Wu Shaoxin, Li Jianhua, Xu Chuanhua. Operating efficiency of village banks based on super-efficiency DEA Model. Finance \& Trade Economics, 2009, 12: 45-49.

[5] Yu Weiping, Luo Jianchao. Research on operation performance and support policies of four village banks in Shaanxi province. Guangdong Agricultural Sciences, 2012, 3: 119-121.

[6] Yang Chaojuan. Evaluation of the Operating Efficiency of Rural Banks in Chongqing City. Rural Economy and Science-Technology, 2019, 3(08): 143,145.

[7] Abdul Qayyum, Munir Ahmad. Efficiency and Sustainability of Micro Finance. Institutions in South Asia. Pakistan Institute of Development Economics. http://ujdigispace.uj.ac.za

[8] Charnes, A., Cooper, W.W. and Rhodes, E. Measuring the Efficiency of Decision-Making Units. European Journal of Operational Research, 1978, 2: 429-444.

[9] Fare, R., Grosskopf, S. and Knox Lovell, C.A. Production Frontiers. Cambridge University Press, Cambridge, 1994.

[10] Wang Junqin, Zong Yixiang, Zhao Banghong. Performance evaluation on the reform of rural credit cooperatives-taking Hebei Province as example. Journal of Agrotechnical Economics, 2010, 6: 82-88.

[11] Li Yanchun, Yang Haifen, Zhao Banghong. Construction of evaluation system of the operating efficiency of rural banks based on DEA model. Southwest Finance, 2012, 7: 28-30.

[12] Liu Lihong. Measure and evaluation of the efficiency of rural credit cooperatives based on DEA model-taking 88 rural credit cooperatives in Guizhou as example. Financial Theory \& Practice, 2010, 4: 59-63.

[13] Mamiza Haq, Michael Skullym, Shams Pathan. Efficiency of Microfinance Institutions: A Data Envelopment Analysis. Asia-Pacific Finance Markets, 2010, 17: 63-97. 